\title{
Digestive Activity of Pancha Harithakadi Churna
}

\author{
S. Sarala ${ }^{1 *}$, D. Chamundeeswari ${ }^{2}$, V. Gopal ${ }^{3}$ \\ 1. Assistant Professor, Department of Pharmacognosy, Hindu College of Pharmacy, Amaravathi Road, Guntur-522002, A.P., India. \\ 2. Professor \& Head, Department of Pharmacognosy, Sri Ramachandra College of Pharmacy, Sri Ramachandra University, Porur, \\ Chennai-600116, T.N., India. \\ 3. Professor \& Principal, Department of Pharmacognosy, Mother Theresa College of Pharmacy, Puducherry-605006, India. \\ *Corresponding author's E-mail: srlchinnam83@gmail.com
}

Received: 16-09-2021; Revised: 22-11-2021; Accepted: 30-11-2021; Published on: 20-12-2021.

\begin{abstract}
The traditional systems of medicine are really effective but the problem with them is they lack in quality assurance. Standardization is the need of the hour in ayurvedic system of medicine. PanchaHarithakadi Churna (PHC) is a traditional polyherbal formulation which consists of five household ingredients used for indigestion. It is mainly used for Constipation and Bloating. Churna's will play a major role in gastro intestinal problems and they have greater bioavailability because of smaller particle size. It consists of fine powder (sieve 100 size) of ginger rhizomes, fennel fruits, myrobalan fruits, senna leaflets and pink rock salt in equal proportions (1:1:1:1:1) are mixed well. PHC was formulated by standard procedures and evaluated by microscopic characterization, inorganic analysis and digestive studies. Microscopical characters indicate the presence of genuine crude drugs used in the formulation. Inorganic analysis shows the presence of calcium, magnesium, sodium, chloride and phosphate. The PHC showed pronounced amylolytic activity and trypsin activity whereas moderate lipolytic activity, proteolytic activity and pepsin activity, mild chymotrypsin activity in treating indigestion. In future we will carry out in vivo digestive studies.
\end{abstract}

Keywords: PHC, Digestion, Inorganic analysis, Enzymes, Ayurveda.

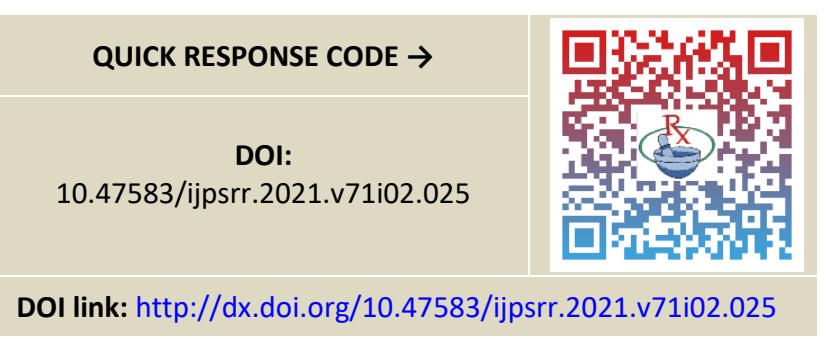

\section{INTRODUCTION}

yurvedic formulations have numerous uses in Ayurveda. They help to rectify the three doshas in the body. ${ }^{1}$ In the last few decades, there has been an exponential growth in the field of ayurvedic medicine. There are great need of standardization and quality control of ayurvedic formulations. The CCRAS and WHO has introduced certain standards and guidelines to maintain uniformity between the production batches. Good manufacturing practices and quality control of the ingredients and products can result in ensuring quality assurance of the formulation. ${ }^{2}$

The present study is to formulate and standardize PHC, which is used to treat gastrointestinal problems. The churna is evaluated by microscopic evaluation, inorganic analysis and digestive studies.

\section{MATERIALS AND METHODS}

\section{Preparation of Churna}

The raw materials such as Ginger rhizomes (1part), Fennel fruits (1part), Myrobalan fruits (1part), Senna leaflets (1part) and Pink Rock salt (1part) were used for the preparation of PHC. The raw materials of PHC were purchased from the market and authenticated by the Botany Department of Hindu College based on their microscopical characters of powdered drugs. All the ingredients were powdered separately, passed through sieve number 100 and mixed together in specified proportions. The churna was packed in an air tight glass container. $^{3}$

\section{Standardization Parameters}

The PHC was standardized by microscopic evaluation, inorganic analysis and digestive studies.

\section{Determination of Microscopic Evaluation}

All the ingredients were powdered and their microscopical characters were observed as shown below. ${ }^{4,5}$

\section{Determination of Inorganic Analysis}

Take the ash of $\mathrm{PHC}$, add $50 \% \mathrm{v} / \mathrm{v} \mathrm{HCl}$ or $50 \% \mathrm{v} / \mathrm{v} \mathrm{HNO}_{3}$ then kept for I hour or longer and filtered. By using filtrate we can perform the following tests. ${ }^{6}$

\section{Tests for Calcium:}

(a) To $10 \mathrm{~mL}$ of filtrate, 1 drop of dil. $\mathrm{NH}_{4} \mathrm{OH}$ and saturated ammonium oxalate solutions were added, white precipitate of calcium oxalate was formed which was soluble in $\mathrm{HCl}$ but insoluble in acetic acid.

(b) Ammonium carbonate solution gives white precipitate which was insoluble in $\mathrm{NH}_{4} \mathrm{Cl}$ solution. 


\section{Tests for Magnesium:}

(a) Heat and cool the filtrate with the solution of sodium phosphate in dilute ammonia solution which gives white crystalline precipitate.

(b) It gives white ppt. with ammonium carbonate solution but not with $\mathrm{NH}_{4} \mathrm{Cl}$ solution.

\section{Test for Sodium:}

Flame test: Thick paste of ash was prepared with conc. $\mathrm{HCl}$, paste was taken on platinum wire loop and introduced to bunsen flame then yellow flame was observed.

\section{Tests for Potassium:}

(a) Few drops of sodium cobalt nitrite solution were added to the filtrate, yellow ppt. of potassium cobalt nitrite was observed.

(b) Flame test: It gives violet flame.

\section{Tests for Iron:}

(a) Few drops of $2 \%$ potassium ferrocyanide were added to the filtrate, dark blue coloration was observed.

(b) Few drops of $5 \%$ ammonium or potassium thiocyanate were added to the filtrate, blood red color was formed.

\section{Test for Sulphate:}

(a) Few drops of $5 \% \mathrm{BaCl}_{2}$ solution were added to the filtrate, white crystalline $\mathrm{BaSO}_{4}$ ppt. was observed which was insoluble in $\mathrm{HCl}$.

(b) It gives white ppt. with lead acetate reagent, which was soluble in $\mathrm{NaOH}$.

\section{Test for Phosphate:}

To $5 \mathrm{~mL}$ of filtrate in $\mathrm{HNO}_{3}$, few drops of ammonium molybdate solution were added and heated for $10 \mathrm{~min}$. then yellow crystalline ppt. of ammonium phosphomolybdate was observed.

\section{Tests for Chloride:}

(a) To $3 \mathrm{~mL}$ of filtrate in $\mathrm{HNO}_{3}$, few drops of $10 \% \mathrm{AgNO}_{3}$ solution were added then white ppt. of $\mathrm{AgCl}_{2}$ was observed which was soluble in dil. ammonia solution.

(b) It gives white ppt. with lead acetate solution, which was soluble in hot water.

\section{Tests for Carbonate:}

(a) It forms $\mathrm{CO}_{2}$ with dilute acid.

(b) It gives brownish red ppt. with $\mathrm{HgCl}_{2}$ solution.

(c) It produces white ppt. with $\mathrm{MgSO}_{4}$ solution.

\section{Tests for Nitrate:}

(a) It liberates red fumes when warmed with $\mathrm{H}_{2} \mathrm{SO}_{4}$ and copper. (b) It does not form brown color with $\mathrm{FeSO}_{4}$ solution but with $\mathrm{H}_{2} \mathrm{SO}_{4}$ it forms brown color at the junction of two liquids.

\section{Determination of Digestive Activity}

\section{Preparation of Extract:}

About 100mg of accurately weighed quantity of churna was extracted with $20 \%$ aqueous glycerol and phosphate buffer ( $\mathrm{pH} \mathrm{7.8)} \mathrm{in} \mathrm{1:4} \mathrm{ratio} \mathrm{and} \mathrm{filtered.} \mathrm{The} \mathrm{filtrate} \mathrm{was}$ used as an enzyme source. The standard sample was prepared similar to the test sample. ${ }^{7}$

\section{Amylolytic activity:}

Extract $(1 \mathrm{ml})$ of churna and standard were incubated separately for 15 minutes at $27^{\circ} \mathrm{C}$ and added to $1 \mathrm{ml}$ of the substrate (soluble starch $1 \%$ in phosphate buffer). The enzyme reaction was interrupted by the addition of $2 \mathrm{ml}$ of DNS reagent and heated for 5 minutes. The absorbance was measured at $520 \mathrm{~nm} .^{8,9}$

\section{Lipolytic Activity}

\section{Preparation of Substrate Solution:}

$2 \mathrm{ml}$ of castor oil was, neutralized to $\mathrm{pH} 7$ and stirred well with the $25 \mathrm{ml}$ of water in the presence of $100 \mathrm{mg}$ of bile salt (sodium taurocholate) till an emulsion was formed. ${ }^{8,9}$

\section{Procedure:}

Take $20 \mathrm{ml}$ substrate and added $5 \mathrm{ml}$ phosphate buffer at $\mathrm{pH}$ 7. The contents were stirred slowly in magnetic stirrer and the temperature was maintained at $35^{\circ} \mathrm{C}$. The electrodes of the $\mathrm{pH}$ meter were dipped in reaction mixture and the ph was adjusted to 7 . The enzymes extract $(0.5 \mathrm{ml})$ was added immediately and ph recorded. The timer was set such that at zero time the $\mathrm{pH}$ was observed as 7. Then $\mathrm{pH}$ dropped by 0.2 units with addition of N/10 $\mathrm{NaOH}$ was noted. The $\mathrm{pH}$ was brought to initial value and was continued for 30 to 60 minutes. The volume of alkali consumed at each time was noted.

$$
\text { Lipolytic activity }=\frac{\text { Volume of alkali } \times \text { Strength of alkali }}{\text { Weight of sample } \times \text { Time in minutes }}
$$

\section{Proteolytic activity}

\section{Preparation of Substrate Solution:}

$200 \mathrm{ml}$ of boiled milk was treated with acetic acid till casein precipitates out. The precipitate was then removed, dried and powdered. One gram of prepared casein was diluted to $100 \mathrm{ml}$ using distilled water. ${ }^{8,9}$

\section{Procedure:}

$1 \mathrm{ml}$ of substrate solution added to $1 \mathrm{ml}$ of $0.1 \mathrm{M}$ phosphate buffer ( $\mathrm{pH} 7.6)$ and $1 \mathrm{ml}$ calcium chloride. To this $1 \mathrm{ml}$ crude enzyme extract was added and digestion stopped after 1hour of incubation with $3 \mathrm{ml}$ of $5 \%$ trichloro acetic acid solution. After 10 minutes precipitate was removed by centrifugation and one portion of supernatant was mixed with $5 \mathrm{ml}$ Lowry's reagent. The mixture was then stained with dilute folin-ciocalteu reagent (1:2) and optical density 
measured at a wavelength of $650 \mathrm{~nm}$. The proteolytic activity was then calculated from standard curve in milligrams of tyrosine. Protein estimated by standard method and results were given in milligrams of liberated tyrosine per milligrams of dissolved protein per hour at $37^{\circ} \mathrm{C}$ as specific activity.

\section{Pepsin Activity}

\section{Preparation of Sample:}

$0.1 \mathrm{~g}$ of PHC was homogenized with $1 \mathrm{~mL}$ Assay buffer, after 2 hours centrifuged at $7000 \mathrm{rpm}(8000 \mathrm{~g})$ at $4^{\circ} \mathrm{C}$ for 10 minutes and the supernatant was kept on ice for detection. ${ }^{10}$

\section{Assay Procedure:}

Warm the substrate to room temperature before use, added the following reagents in the micro centrifugal tubes.

\begin{tabular}{|c|c|c|c|c|}
\hline Reagent & Sample & Control & Standard & Blank \\
\hline Sample & $20 \mu \mathrm{L}$ & - & - & - \\
\hline Substrate & $100 \mu \mathrm{L}$ & $100 \mu \mathrm{L}$ & - & - \\
\hline \multicolumn{5}{|c|}{ Mixed and kept in water bath at $37^{\circ} \mathrm{C}$ for $10 \mathrm{~min}$. } \\
\hline $\begin{array}{l}\text { Stop } \\
\text { Solution }\end{array}$ & $100 \mu \mathrm{L}$ & $100 \mu \mathrm{L}$ & - & - \\
\hline Sample & - & $20 \mu \mathrm{L}$ & - & - \\
\hline \multicolumn{5}{|c|}{$\begin{array}{l}\text { Mixed and centrifuged at } 1000 \mathrm{~g}, 4^{\circ} \mathrm{C} \text { for } 10 \mathrm{~min} \text {, the } \\
\text { supernatant was taken into the microplate. }\end{array}$} \\
\hline Supernatant & $60 \mu \mathrm{L}$ & $60 \mu \mathrm{L}$ & - & - \\
\hline Standard & - & - & $60 \mu \mathrm{L}$ & - \\
\hline $\begin{array}{l}\text { Substrate } \\
\text { diluent }\end{array}$ & - & - & & $60 \mu \mathrm{L}$ \\
\hline $\begin{array}{l}\text { Reaction } \\
\text { Buffer }\end{array}$ & $120 \mu \mathrm{L}$ & $120 \mu \mathrm{L}$ & $120 \mu \mathrm{L}$ & $\begin{array}{l}120 \\
\mu L\end{array}$ \\
\hline Dye Reagent & $20 \mu \mathrm{L}$ & $20 \mu \mathrm{L}$ & $20 \mu \mathrm{L}$ & $20 \mu \mathrm{L}$ \\
\hline
\end{tabular}

\section{Calculation:}

Unit Definition: One unit of Pepsin activity is the enzyme that generates $1 \mu \mathrm{mol}$ of Tyrosine per minute.

According to the weight of sample,

$\operatorname{Pepsin}(\mathrm{U} / \mathrm{g})=22 \times\left(O D_{\text {sample}}-\mathrm{OD}_{\text {control }}\right) /\left(\mathrm{OD}_{\text {standard}}-\mathrm{OD}_{\text {Blank }}\right)$ / W

\section{Trypsin Activity}

\section{Preparation of Sample:}

$0.1 \mathrm{~g}$ of PHC was homogenized with $1 \mathrm{~mL}$ Assay buffer on ice, after 2 hours centrifuged at $7000 \mathrm{rpm}(8000 \mathrm{~g})$ at $4^{\circ} \mathrm{C}$ for 10 minutes and the supernatant was kept on ice for detection. ${ }^{10}$

\section{Assay Procedure:}

Warm the reagents to room temperature before use, added following reagents into the microplates.

\begin{tabular}{|l|c|c|c|}
\hline Reagent & Sample & Standard & Blank \\
\hline Reaction Buffer & $180 \mu \mathrm{L}$ & - & $200 \mu \mathrm{L}$ \\
\hline Substrate & $10 \mu \mathrm{L}$ & - & - \\
\hline Standard & - & $200 \mu \mathrm{L}$ & - \\
\hline $\begin{array}{l}\text { Distilled water } \\
\text { Sample }\end{array}$ & - & - & - \\
\hline $\begin{array}{l}\text { Mixed and measured at } 253 \mathrm{~nm}, \text { recorded the sample } \\
\text { absorbance of } 10^{\text {th }} \text { second and } 130^{\text {th }} \text { second. }\end{array}$ \\
\hline
\end{tabular}

\section{Calculation:}

Unit Definition: One unit of Trypsin activity is defined as the enzyme produce $1 \mu \mathrm{mol}$ Benzoyl-Arginine per minute.

According to the weight of sample,

$\operatorname{Trypsin}(\mathrm{U} / \mathrm{g})=10 \times\left(\mathrm{OD}_{\text {sample(130s) }}-\right.$ ODsample(10s) $) /\left(\mathrm{OD}_{\text {standard- }}\right.$ OD Blank) / W

\section{Chymotrypsin Activity}

\section{Preparation of Sample:}

$0.1 \mathrm{~g}$ of PHC was homogenized with $1 \mathrm{~mL}$ Assay buffer on ice for 1 hour, centrifuged at $7000 \mathrm{rpm}(8000 \mathrm{~g})$ at $4^{\circ} \mathrm{C}$ for 10 minutes and the supernatant was kept on ice for detection. ${ }^{10}$

\section{Assay Procedure:}

Warm the substrate to room temperature before use, added following reagents into the microplate.

\begin{tabular}{|l|c|c|}
\hline Reagent & Sample & Blank \\
\hline Sample & $10 \mu \mathrm{L}$ & - \\
\hline Assay Buffer & - & $10 \mu \mathrm{L}$ \\
\hline Substrate & $190 \mu \mathrm{L}$ & $190 \mu \mathrm{L}$ \\
\hline $\begin{array}{l}\text { Mixed and measured at } 237 \mathrm{~nm}, \text { recorded the sample } \\
\text { absorbance of } 30^{\text {th }} \text { second and } 330^{\text {th }} \text { second. }\end{array}$ \\
\hline
\end{tabular}

\section{Calculation:}

Unit Definition: One unit of Chymotrypsin activity is defined as the OD value changed 0.01 in the reaction system per minute.

Chymotrypsin $(\mathrm{U} / \mathrm{g})=4 \times\left[\left(\mathrm{OD}_{\text {sample(330s) }}-\mathrm{OD}_{\text {sample(30s) })}\right)-\right.$ $\left(O D_{\text {Blank(330s) }}-\mathrm{OD}_{\text {Blank(30s) })]} / \mathrm{W}\right.$

\section{RESULTS}

PHC was standardized by microscopical evaluation, inorganic analysis and digestive studies. Microscopical characters show the presence of genuine drugs rather than adulterated drugs. Inorganic analysis reveals the presence of various inorganic constituents like calcium, magnesium, sodium, chloride and phosphate. Digestive activity was evaluated by amylolytic, lipolytic, proteolytic, pepsin, 
trypsin and chymotrypsin studies in comparison with the standard. The amylolytic activity of a churna was found to be $0.38 \mathrm{mg} / \mathrm{mL}$ at $1 \mathrm{mg} / \mathrm{mL}$ and that of standard was $0.31 \mathrm{mg} / \mathrm{mL}$, lipolytic activity was found to be $0.44 \mathrm{mg} / \mathrm{mL}$ and the standard was $0.58 \mathrm{mg} / \mathrm{mL}$ then proteolytic activity was found to be $0.69 \mathrm{mg} / \mathrm{mL}$ and that of standard was found to be $0.78 \mathrm{mg} / \mathrm{mL}$, pepsin activity was found to be $25.32 \mu \mathrm{mol} / \mathrm{mL}$, trypsin activity was found to be $30.67 \mu \mathrm{mol} / \mathrm{mL}$ and chymotrypsin activity was found to be $4.55 \mu \mathrm{mol} / \mathrm{mL}$.

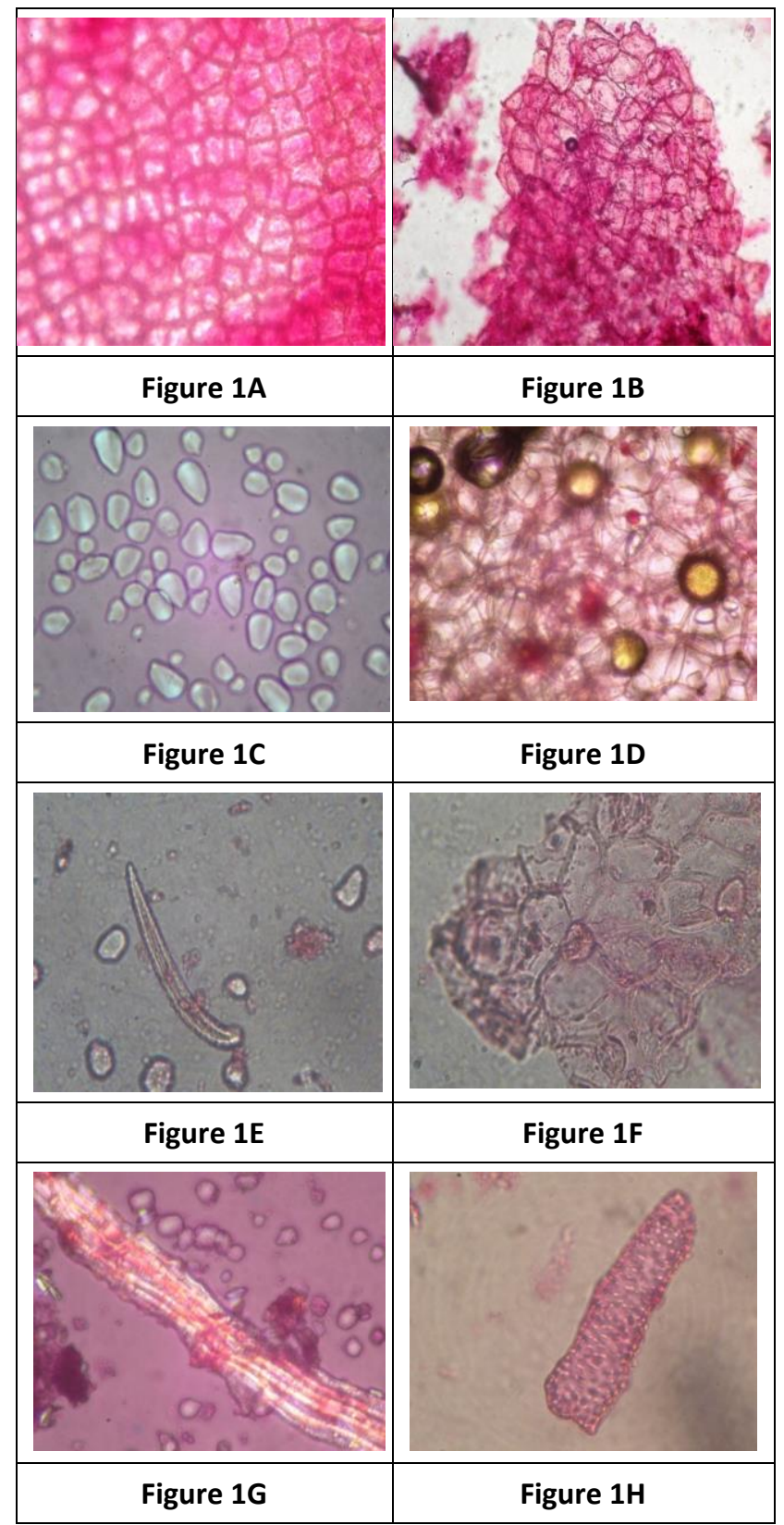

Figure 1: 1A- Epicarp of Fennel, 1B- Mesocarp of Fennel, 1C-Starch of Ginger, 1D- Oleo resin of Ginger, 1E-Covering trichome of Senna, 1F- Paracytic stomata of Senna, 1GFiber bundle of Myrobalan, $1 \mathrm{H}$ - Sclereids of Myrobalan.
Table 1: Inorganic Analysis of PHC

\begin{tabular}{|l|l|}
\hline S. No. & Test \\
\hline 1. & Calcium \\
\hline 2. & Magnesium \\
\hline 3. & Sodium \\
\hline 4. & Potassium \\
\hline 5. & Iron \\
\hline 6. & Sulphate \\
\hline 7. & Phosphate \\
\hline 8. & Chloride \\
\hline 9 & Carbonate \\
\hline 10. & Nitrate \\
\hline
\end{tabular}

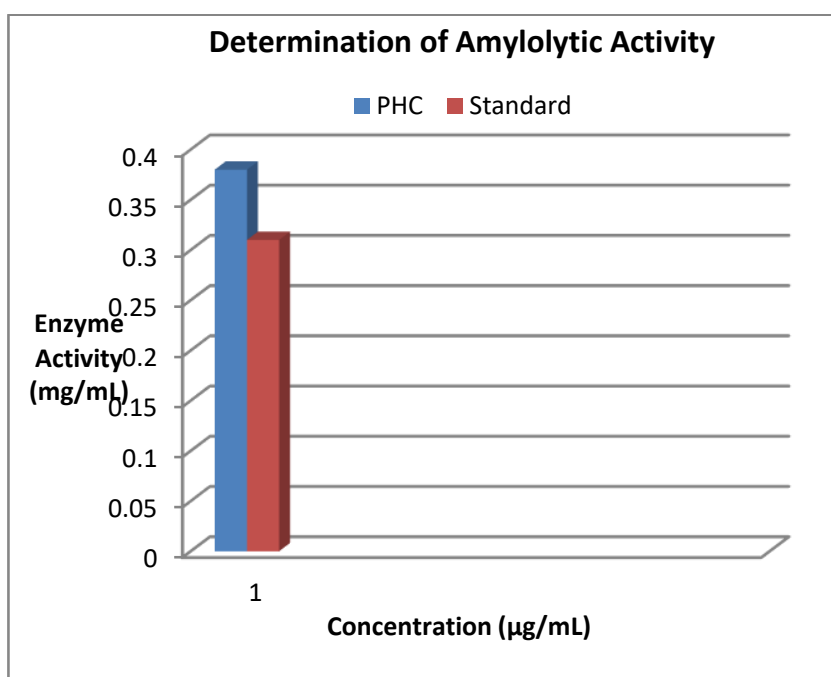

Figure 2: Amylolytic Activity of PHC

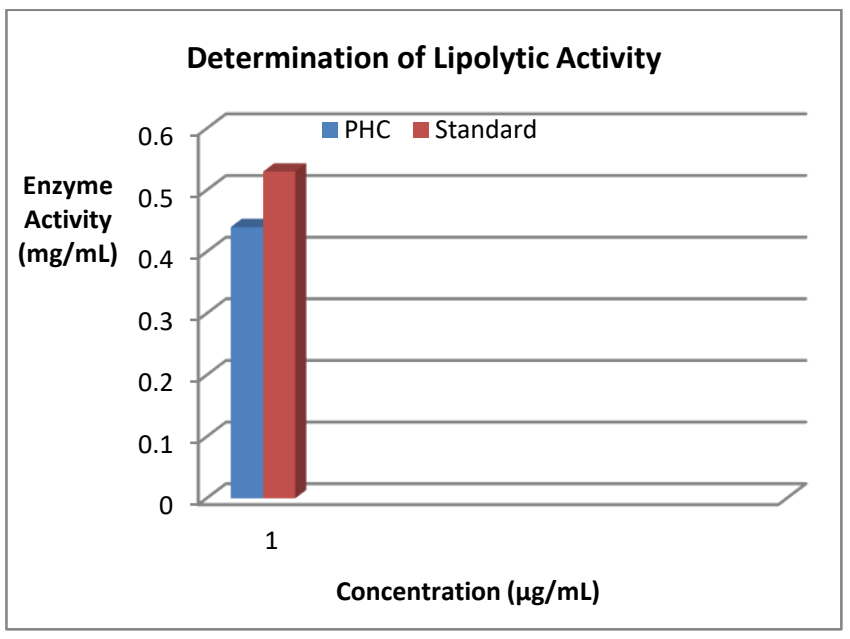

Figure 3: Lipolytic activity of PHC 


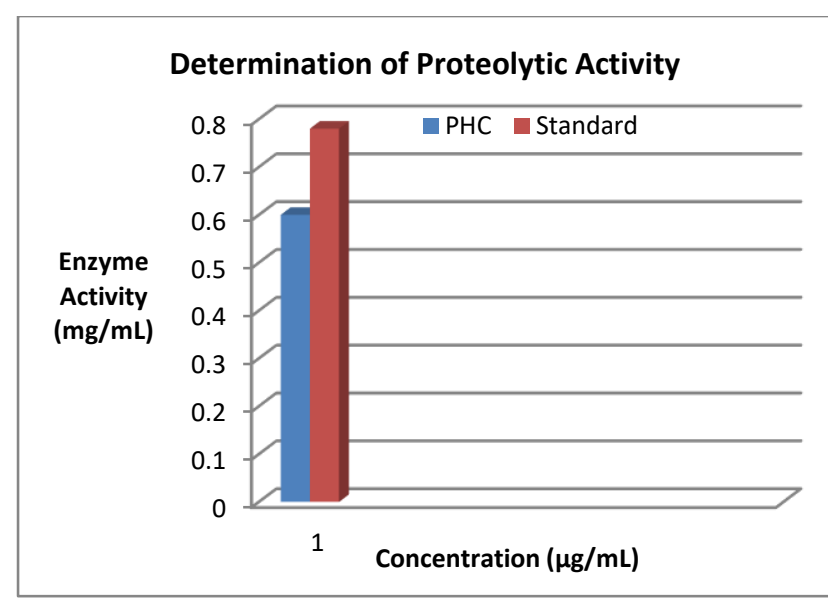

Figure 4: Proteolytic Activity of PHC

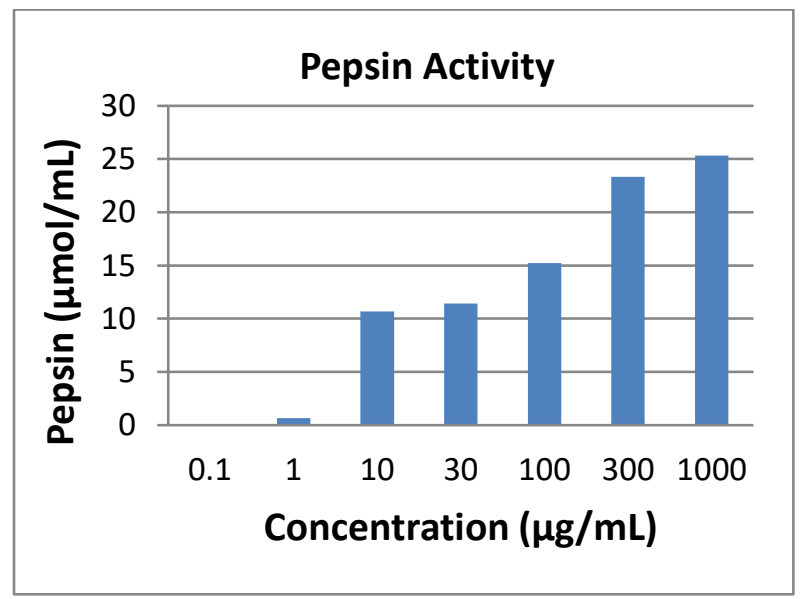

Figure 5: Pepsin Activity of PHC

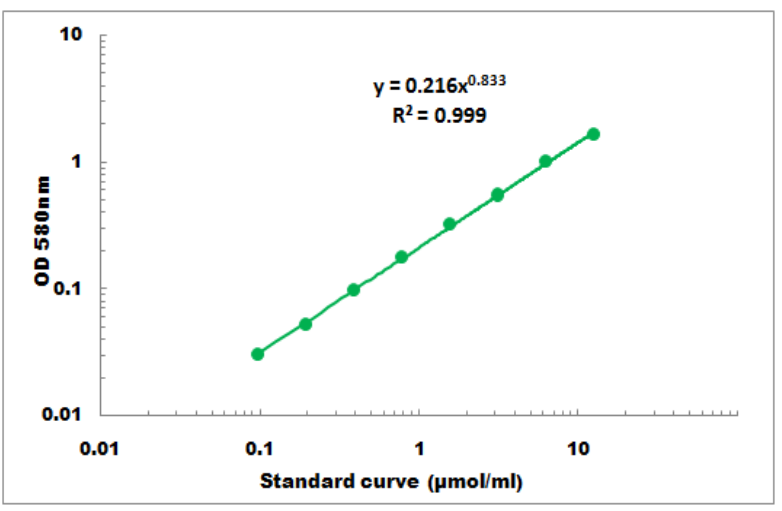

Figure 5A: Standard Curve of Pepsin

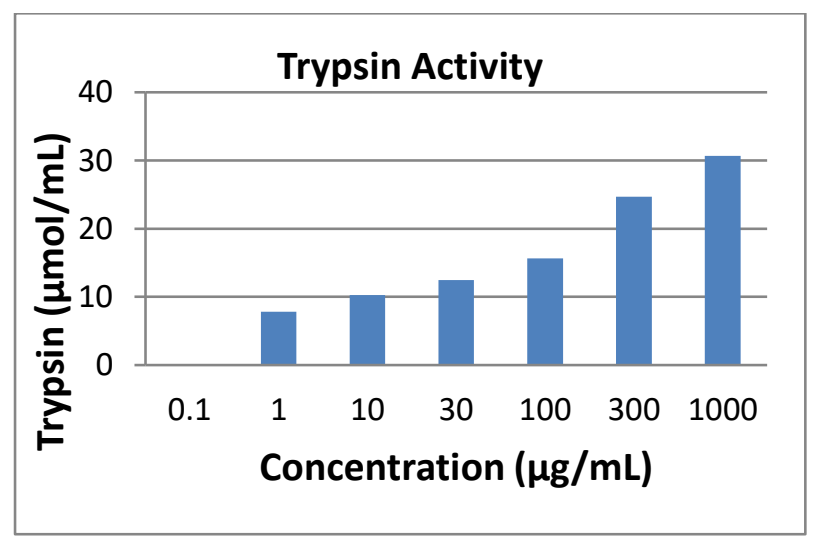

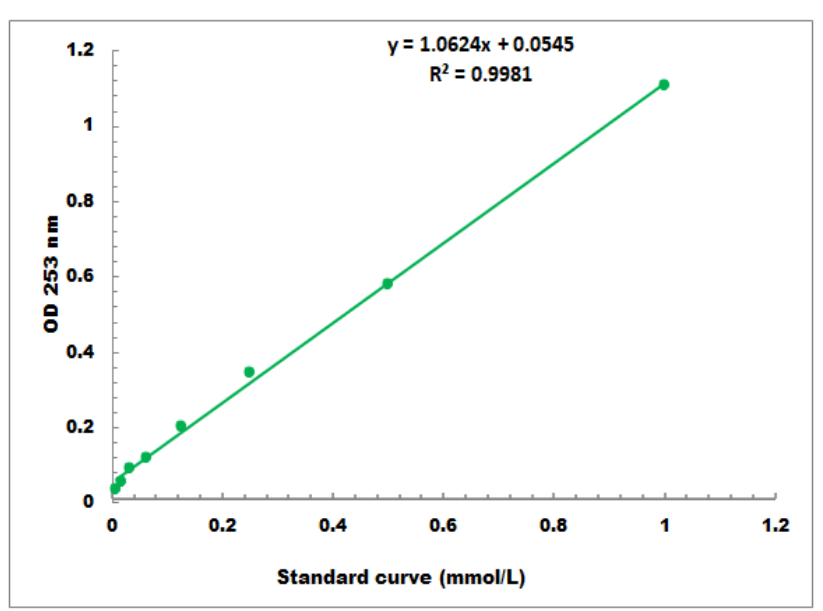

Figure 6A: Standard Curve of Trypsin

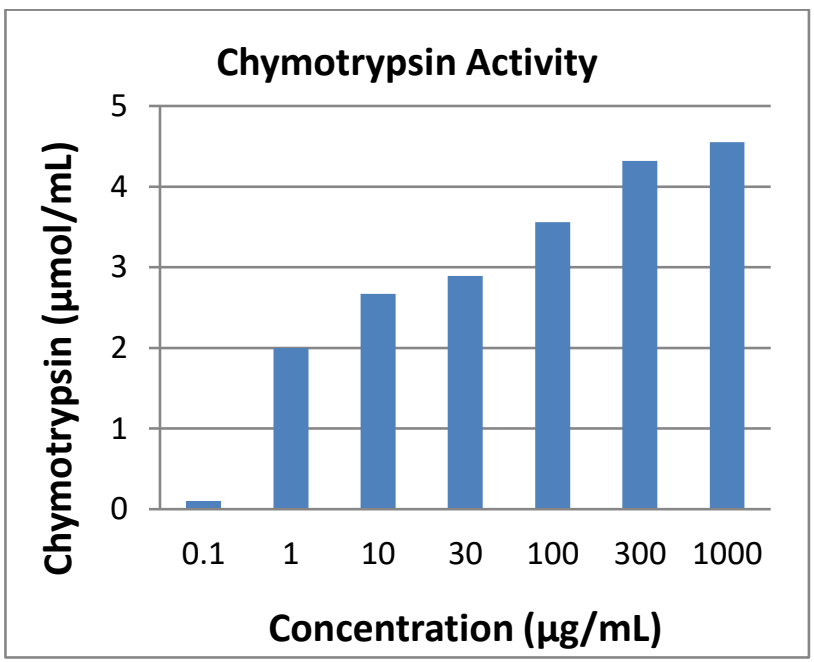

Figure 7: Chymotrypsin Activity of PHC

\section{DISCUSSION}

Churna was subjected to standardization by microscopical characters, inorganic analysis and digestive studies. Microscopical characters suggests that the PHC was comprises of genuine crude drugs having digestive property. Inorganic analysis shows the presence of essential inorganic elements. Digestive studies reveal that churna was having strong amylolytic \& trypsin activity, moderate lipolytic, proteolytic and pepsin activity whereas mild chymotrypsin activity.

\section{CONCLUSION}

Churna has been standardized by modern scientific quality control measures. The microscopical characters, inorganic analysis and digestive studies comply with the WHO standards. The in vitro digestive activity of $\mathrm{PHC}$ reveals the property of digesting carbohydrates, proteins and fats. Further investigation and isolation of compounds is necessary to establish the exact chemical constituents responsible for digestive activity. PHC as rich source of phytoconstituents and interaction of all these chemicals might be revealed in synergistically enhanced the digestive activity.

Figure 6: Trypsin Activity of PHC 


\section{REFERENCES}

1. Rathi A, Rai V, Rawat AKS, Evaluation of Ayurvedic compound formulation III-Laghugangadhar Churna, Ind. J. Traditional Knowledge, 2010; 9: 576-580.

2. Fatima GX, Rahul RS, Chamundeeswari D, Standardization of Marketed Churna an Ayurvedic Polyherbal Formulation, Int. J. Pharm. Sci. Rev. Res., 2014; 28(2): 108-110.

3. Sarala S, Chamundeeswari D, Gopal V, Preparation and evaluation of Pancha harithakadi churna for digestive activity, Int. Res. J. Pharm., 2021; 12(4): 1922.

4. Kokate CK, Practical Pharmacognosy, $1^{\text {st }}$ Edition, Vallabh Prakashan, Pune; 1996, 40-68.

5. Arvind D, Priyanka I, Anatomical investigation of Terminalia chebula, Phytotaxonomy, 2015; 15: 55-62.
6. Khandelwal KR, Practical Pharmacognosy, $12^{\text {th }}$ Edition, Nirali Prakashan, Pune; 2004, 155-156.

7. Harold Varley, Practical clinical biochemistry, $4^{\text {th }}$ Edition, CBS Publishers; 1988, 245.

8. Chamundeeswari D, Kanimozhi P, Vasanthkumar M, Formulation and evaluation of churna for digestive property, Sri Ramachandra Journal of Medicine, November, 2007;23: 39-43.

9. Paul A, Wangano J, Patel G, Pharmacological in vitro investigation for digestive property and in vitro antiulcer activity of pep-up syrup, International journal of green pharmacy, 2014; 8(2): 119-124.

10. Cohesion Biosciences Microplate Assay Kit User Manuals, www.cohesionbio.com, New Delhi.

Source of Support: The author(s) received no financial support for the research, authorship, and/or publication of this article.

Conflict of Interest: The author(s) declared no potential conflicts of interest with respect to the research, authorship, and/or publication of this article.

For any question relates to this article, please reach us at: editor@globalresearchonline.net New manuscripts for publication can be submitted at: submit@globalresearchonline.net and submit_ijpsrr@rediffmail.com 